\title{
Control of Lipase Production by Rhizopus oligosporus under Various Growth Conditions
}

\author{
By ELY NAHAS \\ Departamento de Microbiologia, FCAVJ-UNESP, 14870 Jaboticabal SP, Brasil
}

(Received 6 July 1987; revised 2 September 1987)

\begin{abstract}
Some factors influencing the growth and production of extracellular lipase by Rhizopus oligosporus were studied. Highest yields of enzyme were obtained when Tweens were the carbon source. Soybean meal extract supported good growth and enzyme production. Carbohydrates, vegetable oils, proteins or amino acids did not stimulate lipase production. The fungus grew well with carbohydrate- or protein-supplemented media but not with oils, unless emulsified with a non-metabolizable gum. The production of biomass in static cultures was maximum at $35-40{ }^{\circ} \mathrm{C}$ after $4 \mathrm{~d}$ at $\mathrm{pH} 5.5$. The yield of lipase was maximum at $25^{\circ} \mathrm{C}$ after $3 \mathrm{~d}$ at $\mathrm{pH} 6.5$. Shaking cultures enhanced growth but decreased lipase production.
\end{abstract}

\section{INTRODUCTION}

Rhizopus oligosporus is a fungus used to produce tempeh, a fermented soybean food product (Nahas \& Machado, 1982). This fermentation is reported to enhance the digestibility of soybean (Wang \& Hesseltine, 1965), and the lipolytic activity of the fungus (Wagenknecht et al., 1961) contributes to imparting desirable flavours. Although a considerable amount of information is available on the fermentation of soybean by $R$. oligosporus, few studies have been done in chemically defined media.

Factors affecting microbial extracellular lipase production have been widely studied in bacteria (Lawrence et al., 1967; Mates \& Sudakevitz, 1973), moulds (Chander et al., 1980; Chopra \& Chander, 1983) and yeasts (Ota et al., 1968a,b). Lipases from two Rhizopus spp. have been purified (Iwai \& Tsujisaka, 1974; Aisaka \& Terada, 1981). Few studies have been made with $R$. oligosporus to examine the control of lipase production (Smith \& Alford, 1968) and the growth of the fungus (Sorenson \& Hesseltine, 1966). This study was therefore initiated to investigate the effect of different growth media and conditions on lipase production by $R$. oligosporus.

\section{METHODS}

Chemicals. Olive oil was purchased from Sigma. All other chemicals were of analytical reagent grade.

Culture and inoculum. The organism used was Rhizopus oligosporus Saito, NRRL 2710. Stock cultures were maintained by weekly transfers on Sabouraud agar slants. Inoculum was prepared by washing two freshly subcultured slants with sterile distilled water and filtering through a double layer of commercial gauze to remove contaminating mycelia. Spore suspensions were adjusted to $2 \times 10^{7} \mathrm{ml}^{-1}$.

Basal medium. Citrate mineral salts medium (adjusted to $\mathrm{pH}$ 6.0) was prepared as described by Crocken \& Nyc (1963). When the effect of the carbon source was being considered, carbohydrates, lipids, proteins or amino acids were added. The carbohydrates were sterilized separately and added to the sterile medium before inoculation. Defatted soybean meal extract was prepared by the procedure of Iwai \& Tsujisaka (1974). When the effect of nitrogen source was being studied, ammonium nitrate was replaced with the nitrogen compounds and $1 \%(\mathrm{w} / \mathrm{v})$ glucose was used as the carbon source.

Culture method. A spore suspension $(0.5 \mathrm{ml})$ was inoculated into each Petri dish (14 cm diameter) containing $50 \mathrm{ml}$ medium supplemented with the carbon and/or nitrogen sources. After $72 \mathrm{~h}$, the cultures were filtered through a Büchner funnel, and the mycelial pads were washed with water and pressed between several sheets of 
filter paper. Mycelial mass was expressed as dry weight of the pressed mycelial pads after heating for $24 \mathrm{~h}$ at $98^{\circ} \mathrm{C}$.

Lipase assay. Lipase activity was determined as described by Akhtar et al. (1980), with some modifications. The substrate was a $5 \%(\mathrm{v} / \mathrm{v})$ olive oil emulsion prepared in $1 \%(\mathrm{w} / \mathrm{v})$ gum acacia by homogenizing in a top-drive homogenizer for $6 \mathrm{~min}$; the $\mathrm{pH}$ was adjusted to 8.5 . The reaction mixture contained $2.5 \mathrm{ml}$ substrate, $3.5 \mathrm{ml}$ of $50 \mathrm{~mm}$-Tris/ $\mathrm{HCl}$ buffer, $\mathrm{pH} 8.5$, and $2.0 \mathrm{ml}$ of enzyme solution, diluted twofold after the $\mathrm{pH}$ value had been adjusted to 8.5 . After incubation at $37^{\circ} \mathrm{C}$ for $3 \mathrm{~h}$, the reaction was terminated by the addition of $10 \mathrm{ml}$ acetone/ethanol $(1: 1, \mathrm{v} / \mathrm{v})$. The resulting mixture was then titrated to $\mathrm{pH} 10.5$ against $0.05 \mathrm{M}-\mathrm{NaOH}$. Blanks obtained with enzyme samples boiled for $4 \mathrm{~min}$ were subtracted, and the activities were expressed as $\mu \mathrm{mol}$ free fatty acids released. Determinations were done in duplicate. One unit (U) of lipase activity was defined as the amount of enzyme releasing $1 \mu \mathrm{mol}$ free fatty acids $h^{-1}$. Specific activities were expressed as $U$ (mg dry wt mycelium) $)^{-1}$.

\section{RESULTS}

A range of different carbon sources were tested for their ability to support growth and enzyme production by $R$. oligosporus. Good growth but poor enzyme production was obtained on media supplemented with carbohydrates (Table 1). Mycelial growth and enzyme production on lipidsupplemented media were both very poor except for the polyoxyethylenesorbitans, which gave the highest enzyme activities observed: about $62 \mathrm{U} \mathrm{mg}^{-1}$ with Tween 20 and $67 \mathrm{U} \mathrm{mg}^{-1}$ with Tween 80 (Table 2). Acetic and palmitic fatty acids did not support any mycelial growth. The low mycelial biomass obtained in media supplemented with oils was due to limited availability

Table 1. Effect of different carbohydrates in the medium on the growth and production of lipase by $R$. oligosporus

The organism was grown at $30^{\circ} \mathrm{C}$ for $72 \mathrm{~h}$ in $50 \mathrm{ml}$ of medium; the results are means \pm SEM of four separate cultures. Carbon sources were at $1 \%(w / v)$. This organism was also tested on lactose, sucrose, and glycerol but did not grow.

$\begin{array}{lcccc}\begin{array}{c}\text { Carbon } \\ \text { source }\end{array} & \begin{array}{c}\text { Dry wt. } \\ \left(\mathrm{mg} \mathrm{ml}^{-1}\right)\end{array} & \begin{array}{c}\text { Final } \mathrm{pH} \\ \text { of medium }\end{array} & \begin{array}{c}\text { Lipase activity } \\ {\left[\mathrm{U}(\mathrm{ml} \text { medium })^{-1}\right]}\end{array} & \begin{array}{c}\text { Lipase specific activity } \\ {\left[\mathrm{U}(\mathrm{mg} \text { mycelium })^{-1}\right]}\end{array} \\ \text { Xylose } & 1.5 \pm 0.028 & 5.3 & 4.7 \pm 0.14 & 3.1 \\ \text { Glucose } & 2.0 \pm 0.007 & 4.2 & 3.8 \pm 0.16 & 1.9 \\ \text { Galactose } & 1.1 \pm 0.019 & 5.6 & 5.0 \pm 0.24 & 4.4 \\ \text { Fructose } & 1.9 \pm 0.021 & 4.7 & 1.0 \pm 0.14 & 0.5 \\ \text { Maltose } & 1.6 \pm 0.049 & 5.0 & 2.7 \pm 0.14 & 1.7 \\ \text { Starch } & 1.8 \pm 0.047 & 4.9 & 2.3 \pm 0.14 & 1.3 \\ \text { Mannitol } & 1.6 \pm 0.006 & 5.4 & 3.6 \pm 0.16 & 2.3\end{array}$

Table 2. Effect of different lipid sources in the medium on the growth and production of lipase by $R$. oligosporus

Assay conditions were as in Table 1. Carbon sources were at $0.5 \%(\mathrm{v} / \mathrm{v})$. Oil emulsions were prepared in $0.7 \%(w / v)$ gum acacia.
Carbon
source
$\underset{\left(\mathrm{mg} \mathrm{ml}^{-1}\right)}{\text { Dry wt. }}$
Final pH
of medium
Lipase activity [ $\mathrm{U}(\mathrm{ml} \text { medium })^{-1}$ ]
Lipase specific activity [U (mg mycelium) $)^{-1}$ ]

Cotton oil

Emulsified cotton oil

Rice oil

Emulsified rice oil

Maize oil

Emulsified maize oil

Olive oil

Emulsified olive oil

Soybean oil

Emulsified soybean oil

Tween 20

Tween 80
$0.2 \pm 0.007$

$1.2 \pm 0.006$

$0.3 \pm 0.008$

$0.8 \pm 0.005$

$0.2 \pm 0.005$

$0.9 \pm 0.001$

$0.4 \pm 0.003$

$1.1 \pm 0.030$

$0.4 \pm 0.001$

$1 \cdot 1 \pm 0.039$

$0.4 \pm 0.018$

$0.8 \pm 0.018$

\begin{tabular}{|c|c|c|}
\hline $5 \cdot 8$ & $1 \cdot 2 \pm 0 \cdot 10$ & $7 \cdot 3$ \\
\hline $5 \cdot 5$ & $15.3 \pm 0.21$ & $13 \cdot 2$ \\
\hline $5 \cdot 7$ & $4.5 \pm 0.17$ & 13.9 \\
\hline $5 \cdot 6$ & $18.0 \pm 0.19$ & $21 \cdot 4$ \\
\hline $5 \cdot 8$ & $2 \cdot 2 \pm 0 \cdot 10$ & $12 \cdot 4$ \\
\hline $5 \cdot 6$ & $16.1 \pm 0.34$ & $17 \cdot 4$ \\
\hline $5 \cdot 6$ & $4.2 \pm 0.22$ & $9 \cdot 5$ \\
\hline $5 \cdot 6$ & $16.4 \pm 0.21$ & $14 \cdot 8$ \\
\hline $5 \cdot 6$ & $3.6 \pm 0.21$ & $9 \cdot 1$ \\
\hline $5 \cdot 7$ & $10.6 \pm 0.16$ & $9 \cdot 7$ \\
\hline $5 \cdot 6$ & $27.0 \pm 0.19$ & $61 \cdot 7$ \\
\hline $5 \cdot 7$ & $55.2 \pm 0.33$ & $66 \cdot 7$ \\
\hline
\end{tabular}




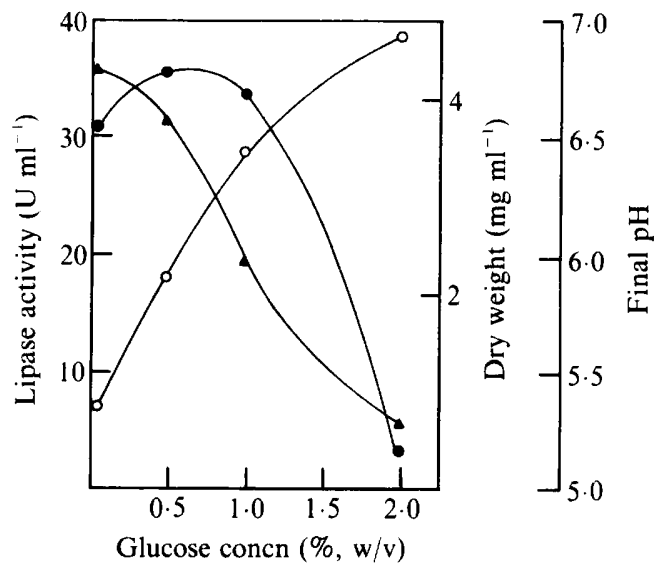

Fig. 1. Production of lipase in cultures of $R$. oligosporus grown on soybean meal extract $(30 \%, \mathrm{v} / \mathrm{v})$ plus glucose $(0.5-2 \cdot 0 \%, w / v)$ at $30^{\circ} \mathrm{C}$ for $72 \mathrm{~h}$. , Lipase activity; $\mathrm{O}$, dry weight of mycelium; $\boldsymbol{\Delta}$, final $\mathrm{pH}$.

Table 3. Effect of various organic nitrogen compounds in the medium on the growth and production of lipase by $R$. oligosporus

Assay conditions were as in Table 1. Carbon sources were at $1 \%(\mathrm{w} / \mathrm{v})$, except for yeast extract, peptone and tryptone that were at $2 \%(\mathrm{w} / \mathrm{v})$, and soybean meal extract at $30 \%(\mathrm{v} / \mathrm{v})$.

\section{Carbon \\ source}

Glutamic acid

Aspartic acid

Arginine

Casein

Casein hydrolysate

Soybean meal extract

Yeast extract

Gelatine

Peptone

Tryptone

$$
\begin{gathered}
\text { Dry wt. } \\
\left(\mathrm{mg} \mathrm{ml}^{-1}\right)
\end{gathered}
$$

\section{$0 \cdot 3 \pm 0.008$}

$0.3 \pm 0.010$

$0.3 \pm 0.015$

$1.5+0.039$

$2.0 \pm 0.012$

$0.7 \pm 0.019$

$2.2 \pm 0.019$

$0.5 \pm 0.021$

$1.2 \pm 0.020$

$2 \cdot 1 \pm 0.064$
Final pH
of medium

$8 \cdot 0$

8.7

$6 \cdot 4$

$8 \cdot 1$

$8 \cdot 0$

$7 \cdot 1$

$8 \cdot 3$

$7 \cdot 6$

$8 \cdot 2$

$8 \cdot 2$
Lipase activity

[ $\mathrm{U}(\mathrm{ml} \text { medium })^{-1}$ ]

$5.6 \pm 0.63$
$4.1 \pm 0.39$
$6.6 \pm 0.52$
$17.3 \pm 0.59$
$29.5 \pm 0.38$
$30.8 \pm 0.46$
$6.3 \pm 0.76$
$11.9 \pm 0.63$
$19.3 \pm 0.69$
$23.6 \pm 0.98$

Lipase specific activity [U (mg mycelium $)^{-1}$ ]

$17 \cdot 8$
$14 \cdot 6$
$20 \cdot 7$
$11 \cdot 3$
$14 \cdot 9$
$47 \cdot 3$
$3 \cdot 0$
$24 \cdot 9$
$16 \cdot 1$
$11 \cdot 2$

$20 \cdot 7$

$11 \cdot 3$

14.9

$47 \cdot 3$

3.0

24.9
$16 \cdot 1$

$11 \cdot 2$

of these carbon sources to the fungus. When emulsified with gum acacia, oils supported good growth and enzyme production (Table 2). Gum acacia on its own did not support growth. The final $\mathrm{pH}$ values of the growth media did not change significantly in the presence of lipids (Table 2); however, carbohydrate-supplemented media decreased the $\mathrm{pH}$ to values ranging between $4 \cdot 2$ and 5.4. $R$. oligosporus was also grown in media containing soybean meal extract in combination with various concentrations of glucose as carbon sources. The results showed that mycelial growth was stimulated by about fivefold when $2 \%(\mathrm{w} / \mathrm{v})$ glucose was added to the medium (Fig. 1). However, lipase production decreased by about ninefold on $2 \%$ glucose as compared with $30.8 \mathrm{U} \mathrm{ml}^{-1}$ in its absence.

Data concerning the effect of amino acids and proteins as carbon sources on the growth of the mould and lipase production are presented in Table 3. Urea was tested but failed to support any growth. Low levels of biomass and enzyme activity were obtained with the amino acids. All the proteins tested, with the exception of soybean meal extract and gelatin, stimulated fungal growth. Significant biomass production was observed with casein hydrolysate, yeast extract and tryptone (Table 3 ). The soybean meal extract promoted maximum lipase production per unit of growth with $R$. oligosporus (about $47 \mathrm{U} \mathrm{mg}^{-1}$ ) (Table 3). The production of lipase in media supplemented with amino acids or proteins ranged between 3 and $21 \mathrm{U} \mathrm{mg}^{-1}$. 


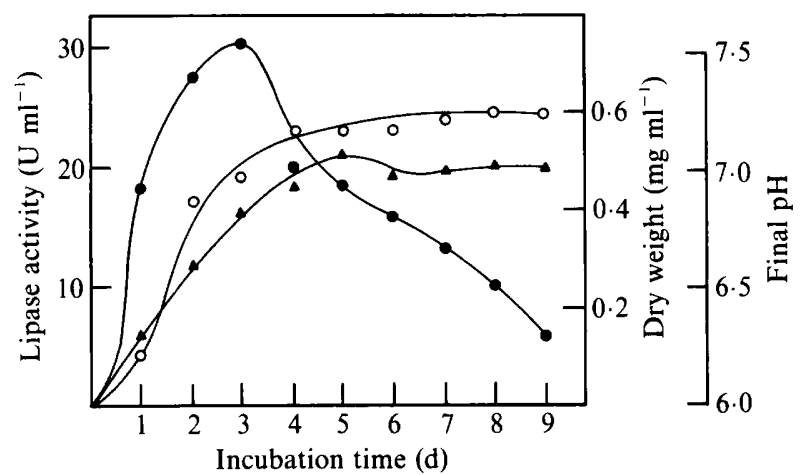

Fig. 2. Effect of period of incubation on the production of lipase by $R$. oligosporus grown on soybean meal extract $(30 \%, v / v)$, at $30^{\circ} \mathrm{C}$. - , Lipase activity; $\bigcirc$, dry weight of mycelium; $\Delta$, final $\mathrm{pH}$.

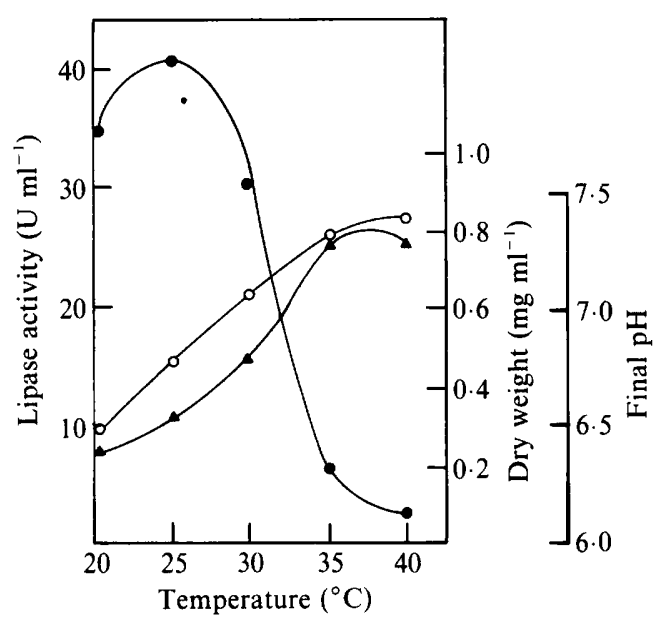

Fig. 3. Effect of temperature of incubation on the production of lipase by $R$. oligosporus grown on soybean meal extract $(30 \%, v / v)$ for $72 \mathrm{~h}$. $O$, Lipase activity; $\bigcirc$, dry weight of mycelium; $\boldsymbol{\Delta}$, final $\mathrm{pH}$.

Salts, amino acids, proteins and urea were used as nitrogen sources in media supplemented with $1 \%$ glucose (Table 4 ). With tryptone as nitrogen source, $R$. oligosporus showed excellent growth, with the biomass production enhanced $182 \%$ as compared to the production with ammonium nitrate. However, the lipase activity per mg dry weight was poor (Table 4). Proteins both as carbon or nitrogen sources raised the $\mathrm{pH}$ values of the culture media, while the amino acids tested increased the $\mathrm{pH}$ values only as carbon sources (Tables 3 and 4).

The effect of the initial $\mathrm{pH}$ on the growth of mould and lipase secretion in soybean meal extract medium was tested between $\mathrm{pH} 4$ and 7 . Although the optimum $\mathrm{pH}$ for growth was at $5 \cdot 5$, enzyme production was highest at $\mathrm{pH} 6 \cdot 5$.

Lipase production was tested over a $9 \mathrm{~d}$ period by using soybean meal extract in the culture medium (Fig. 2). Lipolytic activity in the cell-free culture filtrates was detectable very early in the incubation period. The maximum amount of lipase activity was obtained after $3 \mathrm{~d}$ with recoverable enzyme activity gradually decreasing thereafter and reaching about $19 \%$ of the maximum after $9 \mathrm{~d}$. Biomass production increased up to the fourth day, after which the culture reached the stationary phase (Fig. 2). The decrease in enzyme activity occurred simultaneously with the onset of the stationary phase of fungal growth.

The optimum temperature for lipase production by the fungus was $25^{\circ} \mathrm{C} \mathrm{(Fig.} \mathrm{3);} \mathrm{however,}$ the lipolytic activity at 20 and $30^{\circ} \mathrm{C}$ was about 85 and $75 \%$, respectively, of the optimum. At 
Table 4. Effect of different nitrogen sources on the medium on the growth and production of lipase by $R$. oligosporus

Assay conditions were as in Table 1. Salts, amino acids and urea concentrations were $12.5 \mathrm{mM}$. Casein, casein hydrolysate, peptone and tryptone were at $2 \%(\mathrm{w} / \mathrm{v})$. Soybean meal extract was at $30 \%(\mathrm{v} / \mathrm{v})$. Glucose $(1 \%, w / v)$ was the carbon source.

$\begin{array}{ccccc}\begin{array}{c}\text { Nitrogen } \\ \text { source }\end{array} & \begin{array}{c}\text { Dry wt. } \\ \left(\mathrm{mg} \mathrm{ml}^{-1}\right)\end{array} & \begin{array}{c}\text { Final pH } \\ \text { of medium }\end{array} & \begin{array}{c}\text { Lipase activity } \\ {\left[\mathrm{U}(\mathrm{ml} \text { medium })^{-1}\right]}\end{array} & \begin{array}{c}\text { Lipase specific activity } \\ {\left[\mathrm{U}(\mathrm{mg} \text { mycelium })^{-1}\right]}\end{array}\end{array}$

Ammonium nitrate

Ammonium chloride

$2 \cdot 0 \pm 0.009$

$4 \cdot 2$
$4 \cdot 8$
$6 \cdot 0$

$1.8 \pm 0.021$

Ammonium sulphate

$3.0 \pm 0.018$

$2.6 \pm 0.048$

$6 \cdot 0$

Urea

$3.0 \pm 0.046$

Arginine .

Glycine

Aspartic acid

$1.8 \pm 0.001$

$1.9 \pm 0.016$

Casein

$5.0 \pm 0.002$

Casein hydrolysate

$4.9 \pm 0.075$

Soybean meal extract

Peptone

$3.3 \pm 0.014$

$4.0 \pm 0.050$

Tryptone

$5.5 \pm 0.051$

$3 \cdot 8 \pm 0 \cdot 16$
$7 \cdot 3 \pm 0 \cdot 29$
$4 \cdot 9 \pm 0 \cdot 25$
$11 \cdot 8 \pm 0 \cdot 16$
$2 \cdot 7 \pm 0 \cdot 33$
$2 \cdot 0 \pm 0 \cdot 14$
$11.9 \pm 0.39$
$48 \cdot 8 \pm 0.93$
$34 \cdot 0 \pm 0.24$
$16 \cdot 1 \pm 0 \cdot 16$
$40.5 \pm 0.29$

1.9

$2 \cdot 4$

1.9

3.9

1.5

$1 \cdot 2$

$2 \cdot 4$

$9 \cdot 9$

$10 \cdot 5$

$4 \cdot 0$

$7 \cdot 4$

Table 5. Effect of aeration on growth and lipase production by $R$. oligosporus

Assay conditions were as in Table 1. Carbon sources were at $0.5 \%(\mathrm{v} / \mathrm{v})$ except for soybean meal extract that was at $30 \%(\mathrm{v} / \mathrm{v})$. One set was incubated without shaking and the second aerated by reciprocal shaker $\left(110\right.$ cycles $\left.\min ^{-1}\right)$.

\begin{tabular}{|c|c|c|c|c|}
\hline & $\begin{array}{l}\text { Dry wt. } \\
\left(\mathrm{mg} \mathrm{ml}^{-1}\right)\end{array}$ & $\begin{array}{l}\text { Final pH } \\
\text { of medium }\end{array}$ & $\begin{array}{c}\text { Lipase activity } \\
{\left[\mathrm{U}(\mathrm{ml} \text { medium })^{-1}\right]}\end{array}$ & $\begin{array}{l}\text { Lipase specific activity } \\
{\left[\mathrm{U}(\mathrm{mg} \text { mycelium })^{-1}\right]}\end{array}$ \\
\hline $\begin{array}{l}\text { Soybean oil } \\
\text { Stationary } \\
\text { Shaker }\end{array}$ & $\begin{array}{l}0.5 \pm 0.016 \\
1.9 \pm 0.008\end{array}$ & $\begin{array}{l}5 \cdot 6 \\
5 \cdot 2\end{array}$ & $\begin{array}{r}4.6 \pm 0.21 \\
15.9 \pm 0.25\end{array}$ & $\begin{array}{r}10 \cdot 2 \\
8 \cdot 2\end{array}$ \\
\hline $\begin{array}{l}\text { Soybean meal } \\
\text { Stationary } \\
\text { Shaker }\end{array}$ & $\begin{array}{l}0.6 \pm 0.010 \\
1.0 \pm 0.006\end{array}$ & $\begin{array}{l}7 \cdot 1 \\
7 \cdot 2\end{array}$ & $\begin{array}{l}31.0 \pm 0.24 \\
14.9 \pm 0.27\end{array}$ & $\begin{array}{l}51 \cdot 2 \\
15 \cdot 1\end{array}$ \\
\hline $\begin{array}{c}\text { Tween } 80 \\
\text { Stationary } \\
\text { Shaker }\end{array}$ & $\begin{array}{l}0.8 \pm 0.008 \\
0.9 \pm 0.042\end{array}$ & $\begin{array}{l}5 \cdot 7 \\
5 \cdot 6\end{array}$ & $\begin{array}{l}55.1 \pm 0.43 \\
47.5 \pm 0.55\end{array}$ & $\begin{array}{l}71 \cdot 7 \\
49 \cdot 0\end{array}$ \\
\hline
\end{tabular}

temperatures above $30^{\circ} \mathrm{C}$, the recoverable lipolytic activity was very low (Fig. 3). Increasing temperatures between 20 and $40^{\circ} \mathrm{C}$ also increased mycelial growth at the time of sampling and consequently increased the $\mathrm{pH}$ of the culture medium.

To test the effect of aeration, cultures were incubated at $30^{\circ} \mathrm{C}$ for $3 \mathrm{~d}$ in a reciprocal shaker set at 110 cycles $\mathrm{min}^{-1}$. It becomes evident from these results that aeration influences mycelial growth. Thus, in soybean oil-supplemented medium, fungal growth increased about fourfold, whereas with the other sources tested, the increment was about one to twofold. This greater growth resulted in higher enzyme production $\left(\mathrm{U} \mathrm{ml}^{-1}\right)$; however, when lipolytic activity was expressed as $U(\mathrm{mg} \text { dry } w t)^{-1}$, a significant reduction was observed (Table 5).

\section{DISCUSSION}

The present results show that mycelium (dry wt) and lipase production vary widely under various growth conditions. Thus, carbohydrates were good carbon sources for growth of $R$. oligosporus but low lipase production was obtained. These results agree with those of Alford \& Pierce (1963), Ota et al. (1968a) and Tsujisaka et al. (1973) for lipase in bacteria, yeast and fungi, respectively. 
To further understand the effect of carbohydrates, the growth medium was supplemented with soybean meal extract and increasing concentrations of glucose. Lipase production was strongly repressed by higher concentrations of glucose (Fig. 1). Peters \& Nelson (1948) demonstrated that the presence of glucose in amounts exceeding $0.05 \%$ is detrimental to lipase production by Mycotorula lipolytica. Lipase production in oil-supplemented medium was much lower than in media containing Tween 80 . This decrease of lipase production is comparable with that reported by Chander et al. (1980), who concluded that butter oil and olive oil inhibited lipase activity by 53 and $63 \%$, respectively. Similar observations were made by Lawrence $e$ al . (1967) and Eitenmiller et al. (1970). However, lipase activity in oil-supplemented medium is influenced by exposure of the lipid substrate to attack by the fungus so that increased dispersion of the substrate enhanced growth and enzyme production. Unlike the other lipids used, the Tweens significantly enhanced lipase production. These results are in accordance with those of Ota et al. $(1968 a, b)$, who found that Tweens are able to induce lipase production.

In medium containing proteins either as carbon source or as nitrogen source, lipase secretion was not stimulated, except with soybean meal extract, which resulted in high levels of lipase production (Table 3). These results were similar to those observed by Chopra \& Chander (1983) who found about twofold enhanced lipase production with cornsteep liquor over the other proteins tested. Thus, lipase production with soybean meal extract is comparable with that in the presence of Tweens. $R$. oligosporus is used for soybean fermentation not only because of its high proteolytic and lipolytic activity (Wagenknecht et al., 1961; Wang \& Hesseltine, 1965) but also for improvement of the final flavour (Nahas \& Machado, 1982). The results concerning lipolytic activity in more defined media are in agreement with findings obtained with solid substrates.

Lipase production is also influenced by other factors. Thus, similarly to other fungi (Stern $e t$ al., 1954; Chander et al., 1980) the optimum $\mathrm{pH}$ values for growth and lipase production were 5.5 and 6.5 , respectively. High incubation temperatures $\left(35-40^{\circ} \mathrm{C}\right)$ enhanced the growth of $R$. oligosporus but enzyme production was better at lower temperatures $\left(25^{\circ} \mathrm{C}\right)$. High temperatures may possibly lead to a denaturation of the enzyme. These results are similar to those obtained with Penicillium roqueforti (Eitenmiller et al., 1970) but differ from those obtained for Mucor mucedo by Stern et al. (1954), who reported inhibition of enzyme activity at temperatures below $30^{\circ} \mathrm{C}$. Growth of $R$. oligosporus in soybean oil culture medium was significantly enhanced in shaking cultures, confirming results obtained by Sorenson \& Hesseltine (1966). Thus, in addition to the aeration effect, shaking may have created conditions of higher availability of the carbon source to the fungus. The lipolytic activity $\left(\mathrm{U} \mathrm{ml}^{-1}\right)$ was also higher than in static cultures. However, enzyme production per unit weight was significantly reduced. This may have been due to a possible denaturing effect of shaking (Vadehra \& Harmon, 1969). These results confirm those reported by Chopra \& Chander (1983) for Syncephalastrum racemosum, which produced more lipase when the culture was static.

This work was supported by a grant from the Fundação de Amparo à Pesquisa do Estado de São Paulo (FAPESP) and a fellowship from the Conselho Nacional de Desenvolvimento Científico e Tecnológico (CNPq).

\section{REFERENCES}

Aisaka, K. \& Terada, O. (1981). Purification and properties of lipase from Rhizopus japonicus. Journal of Biochemistry 89, 817-822.

Akhtar, M. W., Mirza, A. Q. \& Chughtal, M. I. D (1980). Lipase induction in Mucor hiemalis. Applied and Environmental Microbiology 40, 257-263.

Alford, J. A. \& Pierce, D. A. (1963). Production of lipase by Pseudomonas fragi in a synthetic medium. Journal of Bacteriology 86, 24-29.

Chander, H., Batish, V. K., Sannabhadti, S. S. \& Srinivasan, R. A. (1980). Factors affecting lipase production in Aspergillus wentii. Journal of Food Science 45, 598-600.
Chopra, A. K. \& Chander, H. (1983). Factors affecting lipase production in Syncephalastrum racemosum. Journal of Applied Bacteriology 54, 163-169.

Crocken, B. \& NYC, J. F. (1963). Utilization of $L-\alpha-$ glycerophorylcholine by a lecithin-deficient strain of Neurospora crassa. Canadian Journal of Microbiology 9, 689-696.

EITENmilleR, R. R., VAKIL, J. R. \& Shahani, K. M. (1970). Production and properties of Penicillium roqueforti lipase. Journal of Food Science 35, 130-133.

IWaI, M. \& Tsujisaka, Y. (1974). The purification and the properties of three kinds of lipase from Rhizopus 
delemar. Agricultural and Biological Chemistry 38, 1241-1247.

LAWrence, R. C., Fryer, T. F. \& Reiter, B. (1967). The production and characterization of lipase from Micrococcus and a pseudomonad. Journal of General Microbiology 48, 401-408.

Mates, . A. \& Sudakevitz, D. (1973). Production of lipase by Staphylococcus aureus under various growth conditions. Journal of Applied Bacteriology 36, 219 226.

NaHAs, E. \& Machado, J. O. (1982). Características biológicas e bioquímicas do farelo de soja após fermentação por Rhizopus oligosporus. Científica 10, $225-232$.

Ota, Y., Suzuki, M. \& Yamada, K. (1968a). Lipids and related substances inducing the lipase production by Candida paralipolytica. Agricultural and Biological Chemistry 32, 390-391.

Ota, Y., MiYairi, S. \& Yamada, K. (1968b) Sterol requirements for the lipase production by Candida cylindracea. Agricultural and Biological Chemistry 32, 1476-1478.

Peters, I. I. \& Nelson, F. E. (1948). Factors influencing the production of lipase by Mycotorula lipolytica. Journal of Bacteriology 55, 581-591.
Smith, J. L. \& Alford, J. A. (1968). Action of microorganisms on the peroxides and carbonyls of rancid fat. Journal of Food Science 33, 93-97.

Sorenson, W. G. \& Hesseltine, C. W. (1966). Carbon and nitrogen utilization by Rhizopus oligosporus. Mycologia 58, 681-689.

Stern, A. M., Ordal, Z. J. \& Halvorson, H. O. (1954). Utilization of fatty acids by and lipolytic activities of Mucor mucedo. Journal of Bacteriology 68, 24-27.

Tsujisaka, Y., IwaI, M., Fukumoto, J. \& OKamoto, Y. (1973). Induced formation of lipase by Geotrichum candidum Link. Agricultural and Biological Chemistry 37, 837-842.

VADEhra, D. V. \& HaRmon, L. G. (1969). Factors affecting production of staphylococcal lipase. Journal of Applied Bacteriology 32, 147-150.

WAGENKNECHT, A. C., MATtick, L. R., Lewin, L. M., Hand, D. B. \& Steinkraus, K. H. (1961). Changes in soybean lipids during tempeh fermentation. Journal of Food Science 26, 373-376.

Wang, H. L. \& Hesseltine, C. W. (1965). Studies on the extracellular proteolytic enzymes of Rhizopus oligosporus. Canadian Journal of Microbiology 11, 727-732. 